\title{
Head of Households in Terengganu
}

\author{
Izzah Sofea Ibrahim ${ }^{1, *}$, Noor Yasmin Zainun ${ }^{1}$, and Nurfilzah Mohd Rawan ${ }^{1}$ \\ ${ }^{1}$ Faculty of Civil and Environment Engineering, University Tun Hussein Onn Malaysia, 86400 Parit \\ Raja, Batu Pahat, Johor, Malaysia
}

\begin{abstract}
In the history of construction development, headship rate has been thought of as a key factor in projecting households. By implementing the household formation, the housing demand can be predicted in line with the objectives of the 10th Malaysia Plan (RMK-10) to match the demand and supply of housing in Malaysia. Case study for this paper was in Terengganu, Malaysia. The objective of this study is to identify the headship rate for the year 1980, 2000 and 2010. Data obtained from the Census of Malaysia was analyzed according to their headship rate for the male and female. Then, the graph was plotted according to gender and age group. Results show that at the early group, the headship rate was increased for male while for female headship rate was increased at elderly age group. Therefore, in conclusion, male in Terengganu more likely to own a home at a young age and vice versa for female.
\end{abstract}

\section{Introduction}

According to Population and Housing Census of Malaysia 2010, average annual population growth rate from the year 2000 until 2010 increase by $2.17 \%$ [1]. The increasing of this population will increased the housing demand as well as in Terengganu district which is the study area. In 2014, the total population at Terengganu was 1.14 million persons, increased to 1.16 million persons in year 2015 and estimated population will increased to 1.18 million persons in the year 2016 [2]. Since the Census was conducted once for 10 years, the headship can classified as stable headship and can be used for 10 years [3]. The previous censuses were conducted in 1970, 1980, 1991, 2000 and 2010. The aim of this paper is to identify the headship rate for the year 1980, 2000 and 2010 in Terengganu. The data later, will used to forecast the household formation in Terengganu but will not discussed in this paper.

The main challenge faced by the government of Terengganu was the issues of property and homes that are affected by supply and demand [4]. If the supply is high but demand is low, the prices will fall. Moreover, National Housing Department reported that 688 units of house was unsold compared 2,236 units that have been built [5]. This imperfection of housing market distorted by external influences such as unethical speculation by housing developers has contribute to the market failure [6].

* Corresponding author: nryasmin@uthm.edu.my 


\section{Headship rate}

The headship rate system has now been generalized to produce a system whereby numbers of households are calculated in terms of number of head of households which are identified by age and gender [7]. Thus far, previous studies suggested that headship rate are then the proportion of person in any age, sex and marital status group who head a household, and number of households can simply be produced for a new projected population by multiplying these rates by the numbers in each population group [8]. [9] Reported that, average household size is the inverse of the average household headship rate, which is defined as the number of persons in the population who are heads of households divided by the population, expressed as a rate as defined in Equation (1),

$$
\text { Headship rate }=\frac{\text { head }}{\text { population }} \times 100
$$

Since this definition controls for variations in population size, variations in the age specific headship rates reflect changes in the propensity of the population within each category to form households [10]. The growth in households is a manifestation of individuals young adult preferring to form their own household based on their needs [11].

The term housing need indicator refers to the lack of the number of households that do not have accommodation while the demand for housing is market-driven concept associated with the type and number of the house where users choose a house based on the preferences and ability to pay [12]. Moreover, housing demand is also defined as the number of homes needed to be one residence per household [13]. Considering all of these evidence, it seems that housing demand was referring to the housing market with the combination of two concepts which is needs and demands.

Zainun et al. [14] found the method to forecasting the housing demand to fulfil the needs of citizens and to avoid a mismatch of demand and needs. In Terengganu, 583 units of abandoned or sick projects have been built and by 532 units have been sold. According [15], the problem of land, supply, cost and others are among the factors contributing to the problem of abandoned projects.

\section{Scope and limitation}

This study was conducted primarily for the purpose of identifying the headship rate on the previous year. 2\% Census data for the year 1980, 2000 and 2010 was synthesizing, analyzing and interpreting in the table and graph. The age group was limit within the age of $15-19,20-24,25-29,30-34,35-39,40-44,45-49,50-54,60-64,65-69,70-74,75-79$ and $80+$.

\section{Methodology}

Headship rate was analysed from the year 1980, 2000 and 2010, the data was obtain from Census of Malaysia [16-18]. Head, population and gender was the most important indicator to be considered in this study [19]. Fig. 1 illustrates the flow of this study. The Census data obtained from the Department of Statistics Malaysia was synthesis by age group. Early group within the age of 15-19 until 80 above was considered based on the marital status [20]. Two group of gender which is male and female were categorised, then the data will be synthesis by head and population within the age group. By using formula that has mention 
earlier, the headship rate can be identified. Headship rate for male and female in the year 1980, 2000 and 2010 was interpreted in the Table 1 and Table 2.

Example calculation of the headship rate for the male in the year 1980 which is age group 15-19 was shown below:

$$
\text { Headship rate }=\frac{20(\text { male head })}{444(\text { male population })} \times 100=4.5 \%
$$

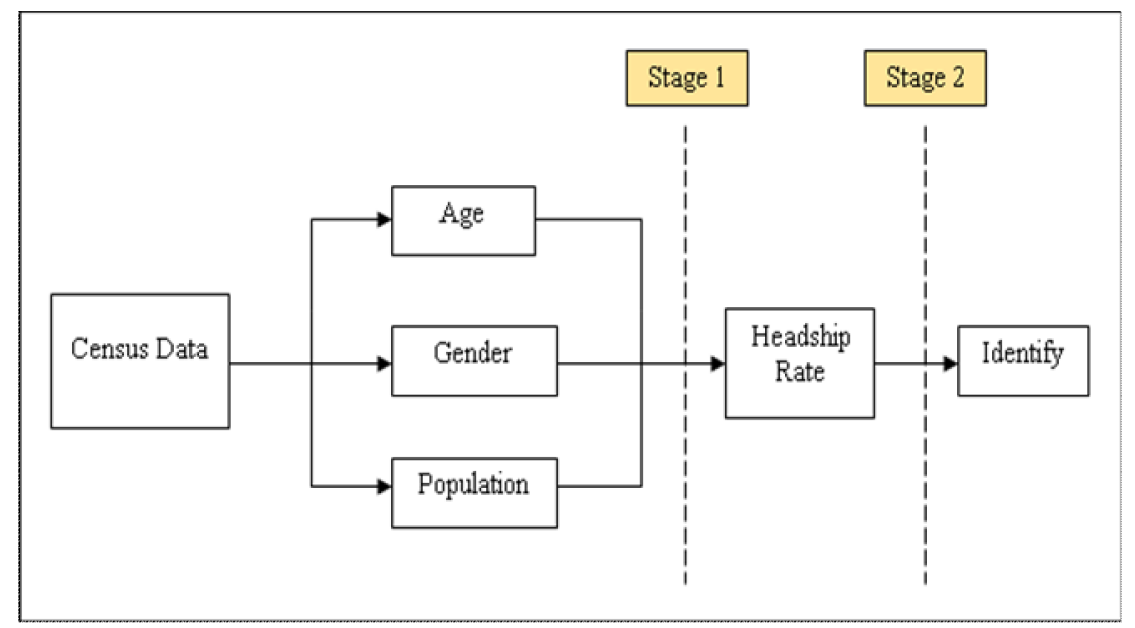

Fig. 1. The flow of this study.

Table 1. Headship rate for male year 1980, 2000 and 2010

\begin{tabular}{|c|c|c|c|c|c|c|c|c|c|}
\hline \multirow{2}{*}{$\begin{array}{c}\text { Age } \\
\text { Group }\end{array}$} & \multicolumn{9}{|c|}{ YEAR } \\
\cline { 2 - 9 } & $\begin{array}{c}\text { Male } \\
\text { Heads }\end{array}$ & $\begin{array}{c}\text { Male } \\
\text { Population }\end{array}$ & $\begin{array}{c}\text { Headship } \\
\text { Rate }\end{array}$ & $\begin{array}{c}\text { Male } \\
\text { Heads }\end{array}$ & $\begin{array}{c}\text { Male } \\
\text { Population }\end{array}$ & $\begin{array}{c}\text { Headship } \\
\text { Rate }\end{array}$ & $\begin{array}{c}\text { Male } \\
\text { Heads }\end{array}$ & $\begin{array}{c}\text { Male } \\
\text { Population }\end{array}$ & $\begin{array}{c}\text { Headship } \\
\text { Rate }\end{array}$ \\
\hline $15-19$ & 20 & 444 & 4.50 & 15 & 929 & 1.61 & 1 & 1119 & 0.09 \\
$20-24$ & 83 & 329 & 25.23 & 57 & 582 & 9.79 & 69 & 965 & 7.15 \\
$25-29$ & 154 & 276 & 55.80 & 231 & 565 & 40.88 & 233 & 814 & 28.62 \\
$30-34$ & 211 & 263 & 80.23 & 377 & 536 & 70.34 & 332 & 588 & 56.46 \\
$35-39$ & 196 & 222 & 88.29 & 461 & 550 & 83.82 & 398 & 557 & 71.45 \\
$40-44$ & 193 & 213 & 90.61 & 455 & 500 & 91.00 & 459 & 549 & 83.61 \\
$45-49$ & 122 & 129 & 94.57 & 396 & 421 & 94.06 & 499 & 535 & 93.27 \\
$50-54$ & 113 & 120 & 94.17 & 337 & 351 & 96.01 & 449 & 486 & 92.39 \\
$55-59$ & 104 & 115 & 90.43 & 210 & 220 & 95.45 & 358 & 375 & 95.47 \\
$60-64$ & 92 & 98 & 93.88 & 173 & 178 & 97.19 & 237 & 252 & 94.05 \\
$65-69$ & 61 & 76 & 80.26 & 82 & 91 & 90.11 & 182 & 191 & 95.29 \\
$70-74$ & 44 & 50 & 88.00 & 81 & 89 & 91.01 & 138 & 158 & 87.34 \\
$75-79$ & 25 & 32 & 78.13 & 57 & 62 & 91.94 & 55 & 65 & 84.62 \\
$80+$ & 10 & 16 & 62.50 & 43 & 54 & 79.63 & 68 & 99 & 68.69 \\
\hline
\end{tabular}


Table 2. Headship rate for female year 1980, 2000 and 2010

\begin{tabular}{|c|c|c|c|c|c|c|c|c|c|}
\hline \multirow{2}{*}{$\begin{array}{c}\text { Age } \\
\text { Group }\end{array}$} & \multicolumn{9}{|c|}{ 1980 } \\
\cline { 2 - 9 } & $\begin{array}{c}\text { Female } \\
\text { Heads }\end{array}$ & $\begin{array}{c}\text { Female } \\
\text { Population }\end{array}$ & $\begin{array}{c}\text { Headship } \\
\text { Rate }\end{array}$ & $\begin{array}{c}\text { Female } \\
\text { Heads }\end{array}$ & $\begin{array}{c}\text { Female } \\
\text { Population }\end{array}$ & $\begin{array}{c}\text { Headship } \\
\text { Rate }\end{array}$ & $\begin{array}{c}\text { Female } \\
\text { Heads }\end{array}$ & $\begin{array}{c}\text { Female } \\
\text { Population }\end{array}$ & $\begin{array}{c}\text { Headship } \\
\text { Rate }\end{array}$ \\
\hline $15-19$ & 10 & 450 & 2.22 & 1 & 936 & 0.11 & 0 & 990 & 0.00 \\
$20-24$ & 23 & 395 & 5.82 & 22 & 538 & 4.09 & 37 & 902 & 4.10 \\
$25-29$ & 33 & 344 & 9.59 & 21 & 548 & 3.83 & 36 & 654 & 5.50 \\
$30-34$ & 21 & 224 & 9.38 & 21 & 571 & 3.68 & 27 & 572 & 4.72 \\
$35-39$ & 33 & 235 & 14.04 & 26 & 540 & 4.81 & 42 & 572 & 7.34 \\
$40-44$ & 37 & 210 & 17.62 & 32 & 489 & 6.54 & 43 & 578 & 7.44 \\
$45-49$ & 36 & 147 & 24.49 & 45 & 395 & 11.39 & 62 & 568 & 10.92 \\
$50-54$ & 25 & 116 & 21.55 & 58 & 273 & 21.25 & 91 & 461 & 19.74 \\
$55-59$ & 41 & 128 & 32.03 & 54 & 212 & 25.47 & 87 & 354 & 24.58 \\
$60-64$ & 29 & 101 & 28.71 & 63 & 188 & 33.51 & 92 & 277 & 33.21 \\
$65-69$ & 24 & 58 & 41.38 & 31 & 104 & 29.81 & 74 & 202 & 36.63 \\
$70-74$ & 18 & 55 & 32.73 & 41 & 99 & 41.41 & 85 & 166 & 51.20 \\
$75-79$ & 8 & 29 & 27.59 & 31 & 55 & 56.36 & 28 & 61 & 45.90 \\
$80+$ & 13 & 26 & 50.00 & 35 & 85 & 41.18 & 50 & 113 & 44.25 \\
\hline
\end{tabular}

\section{Results and discussion}

The trend of the graph on Fig. 2 shows that the headship rate increasing at the early age group and remain constant at the middle of age group then decrease when come to older age group. The higher of headship rate at early group because of the improved material situation of and propensity to leave the parental home of young people [21]. Moreover, this result will impacted to projecting the household formation in Terengganu. Higher increasing of headship rate from the age group of 25-29 to $30-34$ was increased by $27.8 \%$ for the year 1980 while the lower decreasing headship rate from 75-79 to 80 and above was decreased by $15.9 \%$. Moreover, headship rate for the year $2000,31.1 \%$ was increased from the age group of 20-24 to $25-29$ while $30.6 \%$ for the year 2010 from the same age group. The lower decreasing headship rate for the year 2000 and 2010 from the same age group which is $75-79$ to 80 and above with the value $12.3 \%$ and $15.6 \%$ respectively.

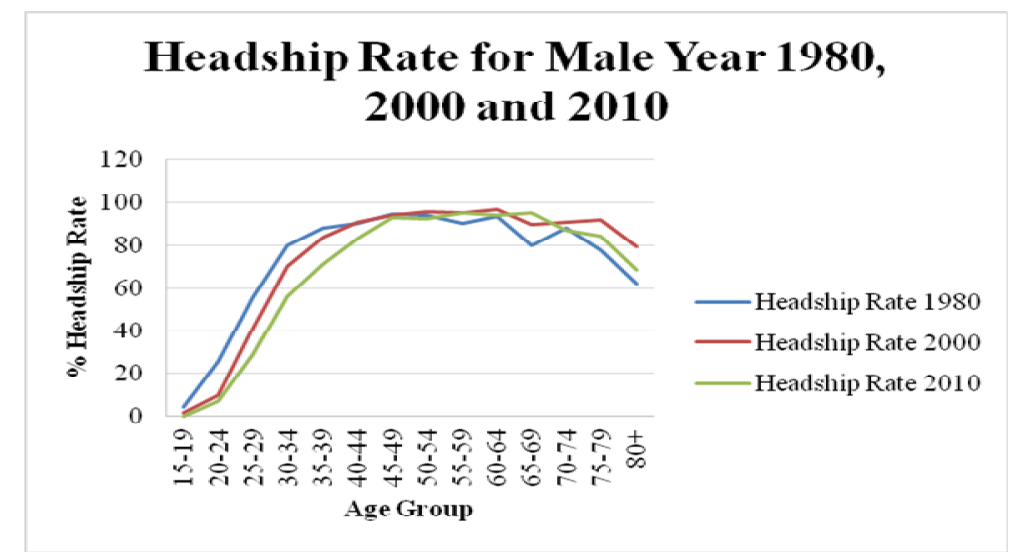

Fig. 2. Headship rate for male year 1980, 2000 and 2010. 
Fig. 3 shows the headship rate for female for year 1980, 2000 and 2010 graph was fluctuating. [22] reported that the factor of this fluctuating was income, marriage and education. The higher increasing of headship rate mostly comes from the elderly age group. This results corresponding on the previous research by Moonie (2013) reported that the relatively high headship rate among elderly may be linked in demographic change by transition from high fertility and mortality rate thus possibly a higher number of older person living alone [23]. For the year 1980, age group of 65-69 to 70-74 showed that the highest increasing of headship rate by $14.6 \%$ while $5.3 \%$ the lowest decreasing from the age group 70-74 to 75-79. Besides that, $14.9 \%$ from the age group 70-74 to 75-79 was the highest increasing in headship rate and $15.2 \%$ from the age group 75-79 to 80 and above was the lowest decreasing. Last but not least, the higher increasing of headship rate for the year 2010 from the age group of $75-79$ to 80 and above was increased by $22.4 \%$ while the lower decreasing was $8.6 \%$ decrease from the age group of 65-69 to 70-74.

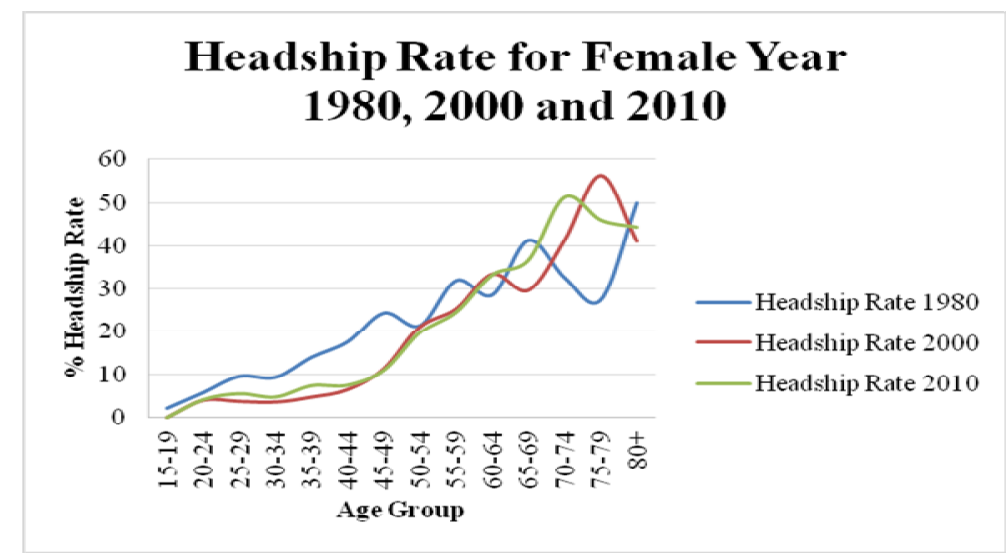

Fig. 3. Headship rate for female year 1980, 2000 and 2010.

\section{Conclusion}

In a nutshell, headship rate was increased at the early age group for the male while at the elderly age group for the female. This increased because of the factor of marital status and fatality. By considering the headship rate, the household formation can be forecasting accurately based on their demand. This study hoped can be helpful to the government sector and private agencies to construct housing.

This research was collaboration between UTHM and Sirim Berhad under special grant funded by MOSTI. The authors whould like to thank University Tun Hussein Onn Malaysia, Sirim Berhad and MOSTI for financial support and priority necessary infrastructure to carry out research work.

\section{References}

[1] Department of Statistics Malaysia, Population and housing census of Malaysia 2010, Department of Statistics Malaysia, 77, (2011)

[2] Department of Statistics, Population quick info, (2016), Retrieved on July 9, 2016 from http://pqi.stats.gov.my

[3] L. Goodman, R. Pendall, and J. Zhu, Headship and homeownership: What does the future hold?, Urban Institute, Washington, (2015)

[4] N. Yatim, Hartanah di Kuala Terengganu Mahal, Sinar Harian, 35, (October 8, 2014). 
[5] National Housing Department, Laporan Perangkaan Suku Tahun Pertama 2016, 1-21 (2016)

[6] A. Rameli, D.F. Johar, and A.P.D.H. Siong, The management of housing supply in malaysia: incorporating market mechanisms in housing planning process, Int. Conference on Construction Industry 2006, 1-17, (2006)

[7] United Nations, Headship rate method, (1957), Retrieved on May 1, 2016 from http://www.un.org/esa/population/techcoop/SocInd/manual7/chapter4.pdf

[8] J.F. Ermisch, and E. Overton, Minimal household units: A new approach to the analysis of household formation, Population Studies, 39(1), 33-54, (1985)

[9] F.L. Mackellar, W. Lutz, C. Prinz, and A. Goujon, Population, households, and CO2 emissions, Population and Development Review, 21(4), 849-865, (1995)

[10]L.B. Smith, Household headship rate, Household Formation and Housing Demand in Canada, 60(2), 180-188, (1984)

[11] M. Carliner, Headship rates and housing demand, Housing Economics, 8-12, (2013)

[12] S. Heath, Housing demand and need, Social Policy Section, 1-21, (2014)

[13]J.Z. Hansen, P. Stephensen, and J.B. Kristensen, Household formation and housing demand forecasts, (2013), Retrieved on May 5, 2016 from www.dreammodel.dk/SMILE

[14]N.Y. Zainun, I.A. Rahman, and M. Eftekhari, Forecasting low-cost housing demand in pahang, malaysia using artificial neural networks, J. of Mathematic Research, 2(1), 14$19,(2011)$

[15]M.F. Hashim, Kesan punca masalah projek sakit, Utusan Malaysia, Kuala Lumpur, (February 16, 2010).

[16]Department of Statistics Malaysia, 2\% population and housing census of Malaysia 1980, Putrajaya, Malaysia, (1980)

[17]Department of Statictics Malaysia, 2\% population and housing census of Malaysia 2000, Putrajaya, Malaysia, (2000)

[18]Department of Statistics Malaysia, 2\% population and housing census of Malaysia 2010, Putrajaya, Malaysia (2010)

[19] S. De Vos, and K. Holden, Measures comparing living arrangements of the elderly: Assessment, Population and Development Review, 14(4), 688-704, (2007)

[20]F.T.S. Court, Acts Islamic Family Law (Federal Territories) 1984, (1993)

[21]N. Keilman, Recent trends in family and household composition in Europe, Euopean. J. of Population, 3(3-4), 297-325, (1988)

[22]R.A. Moffitt, Welfare benefits and female headship in US time series, The American Economic Review, 90(2), 373-377, (2000)

[23] S.C. Moonie, The projected impact of demographic changes on household size and housing stock in Saint Lucia: 2015-2030, Master Thesis, The University of the West Indies, Mona, Kingston, Jamaica, (2013) 